\title{
IMPACT OF POLDER SYSTEM ON FLOODING IN THE ROLAVA RIVER BASIN
}

\begin{abstract}
TAUFMANNOVÁ, A., JENÍČEK, M. (2011): Impact of polder system on flooding in the Rolava River basin. Geografie, 116, No. 2, pp. 130-143. - This paper deals with evaluating the impact of dry reservoirs on flood events. The system of dry reservoirs could create an effective part of integrated flood protection. The system of four uncontrolled dry reservoirs was theoretically implemented to the headwater part of the Rolava River basin in the Ore Mountains. The main aim was to evaluate the potential impact of the dry reservoirs on peak discharge decrease during two known rainfall events in September 2007 and in August 2006 and four theoretical scenarios - 10, 20, 50 and 100-year return period of 1-day precipitation. Rainfall-runoff modelling was carried out by means of the model HEC-HMS (Hydrologic Engineering Center - Hydrologic Modeling System) with satisfactory agreement in the calibration and verification process.

KEY WORDS: Rainfall-runoff modeling - HEC-HMS - flood protection - Rolava River basin - dry reservoirs.
\end{abstract}

The presented research was funded by the Ministry of Education, Youth and Sports of the Czech Republic, project No. MSM 0021620831 "Geographical Systems and Risk Processes in the Context of Global Changes and European Integration".

\section{Introduction}

The modern complex approach to the flood protection solution has been developed nowadays (Just et al. 2005). The new paradigm has resulted in the concept of "integrated flood protection", based on the maximum use of the retention and transformation potential of the landscape (Langhammer 2008). Conceptually different and complicated arrangements and applications can have a positive flood protection impact on the landscape. Peak discharges and, consequently, potential damages could be reduced by an accurate combination of several flood protection arrangements. System of dry reservoirs could represent one of the effective flood protection solutions. Water accumulation in dry reservoirs can increase the storage capacity of a river flood plain on a local scale. Dry reservoirs are generally considered suitable parts of a natural area (Langhammer, Šobr, Vaněk 2008).

Small mountain river basins are sensitive to intensive precipitation events. The response to such rainfall could be flash floods causing extreme discharge in a short time period and sudden damage to the environment and property (Langhammer, Vilímek, Křížek 2003; Vilímek, Spilková, 2009). Runoff in upper river basin areas is driven by several factors, which influence especially flood wave time distribution (Kliment, Matoušková 2009). The landscape char- 


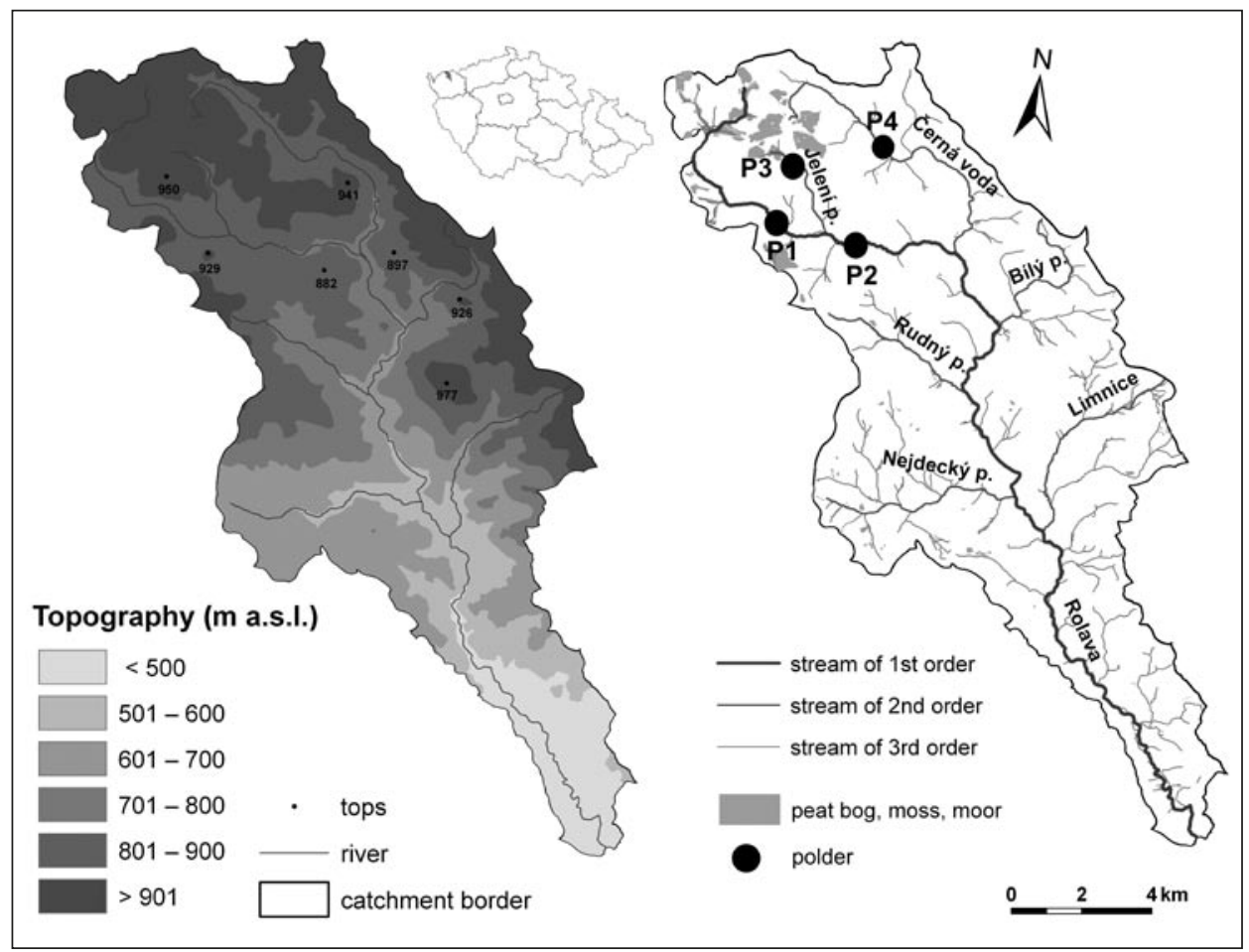

Fig. 1 - Rolava River basin topography (left) and hydrography (right) (DIBAVOD, ZABAGED)

acter can be affected by placement of drastic flood protection arrangements in the mountain area (Janský, Kocum 2008). A solution of peak discharge drop should be the applied effective flood protection arrangement option. The system of dry reservoirs represents such kind of an arrangement. This paper deals with four dry reservoirs as examples of flood protection tools theoretically implemented to the headwater part of the Rolava River basin. Jeníček (2008) applied a similar study in the Chomutovka river basin. In this study dry reservoirs are classified as small water reservoirs according to the Czech National Standard 752410 (ČSN 75 2410). Small water reservoirs are defined by maximal depth which is $9 \mathrm{~m}$ and maximal reservoir volume which is $2 \mathrm{mil} . \mathrm{m}^{3}$ (Herynek, Tlapák 2002).

The main aim of the paper was to analyze the Rolava River basin behavior during selected observed and theoretical rainfall events. Rainfall-runoff modelling was carried out by means of HEC-HMS model (Hydrologic Engineering Center - Hydrologic Modeling System). HEC-HMS does not include hydraulic modelling in dry reservoirs and does not consider any manipulation of dry reservoirs. HEC-HMS describes dry reservoirs as retention areas using no flood wave transformation function. Rivers flow through dry reservoirs that act as uncontrolled reservoirs being not saturated all the time. The main assumption for modelling with dry reservoirs, set up in HEC-HMS, is equality in inflow and outflow amount. The detailed technical dry reservoir description was not considered the main aim of this paper. 
The impact of four dry reservoirs on the peak discharge drop in the river basin outlet during two known rainfall events and four rainfall scenarios with the return period of $10,20,50$ and 100 years was evaluated. Building up an accurate model in the HEC-HMS environment was required to yield a high probability of successful modelling results. The river basin model in HEC-HMS was considered to be similar to the real river basin and therefore suitable to generate similarities in observed and modelled hydrographs.

Modelling the impact of dry reservoirs was carried out in the Rolava River basin in the Ore Mountains to Stará Role outlet near Karlovy Vary in the Czech Republic (Fig. 1). The river basin area to the outlet is $125.3 \mathrm{~km}^{2}$, the Rolava River is $32.5 \mathrm{~km}$ long to the same outlet. The river springs in the top part of the Ore Mountains at an altitude $920 \mathrm{~m}$ on the table plain. The Rolava River flows to the Ohře River in Karlovy Vary as a sinistral tributary.

The character of the Rolava River basin is not unique in terms of basin division in upper, middle and down stream area (Fig. 1). The spring top part is largely supplied by rainfall. The peaty soils contribute to direct runoff from the area. The river tends to flow faster in the middle part of the river basin because of the steep valley and undeveloped flood plain. The only option for the river to be flooded out during extreme rainfall could occur in the lower part of the river basin. Flood protection arrangements in the mountain areas are therefore useful in the upper basin parts to catch potential flood waves. Consequently the theoretic system of four dry reservoirs was implemented in the upper headwater part of the Rolava River basin.

\section{Material and methods}

\subsection{Data sources and software}

Several data was used and processed to reach the final results. The rainfall-runoff series represented the first group of data processed in this paper. The time series belong to the data sets distributed by the Czech Hydrometeorological Institute in Prague (CHMI), Povodí Ohře, s. p. and Deutscher Wetterdienst (DWD). Specifically the mean daily and hourly rainfall and runoff data in the specified time period were used. The CHMI also provided the mean daily precipitation amount with recurrence of $10,20,50$, and 100 years for down, middle and upper part of the basin. A more detailed resolution for precipitation amounts was not available. The other data set was Digital Terrain Model (DTM) created from the ZABAGED database and fieldwork. Fieldwork provided reservoir shape, bathymetry and river cross sections measurements.

The base map source of data was the DTM which helped to analyze the river basin spatially. The results of such analyses represented essential input information for modelling calculations in the HEC-HMS. Hydrologicaly correct DTM was created by means of ArcGIS extension ArcHydro Tools (Maidment 1993). The rainfall-runoff simulations, model calibration and verification were run in the model HEC-HMS. HEC-HMS as a hydrological modelling tool has been used for a variety of hydrological analyses in Czechia (Kulasová, Šercl, Boháč 2004) and in foreign research as well (Brath, Montanari, Moretti 2005; 
Table 1 - Dry reservoir parameters

\begin{tabular}{|lcccccc|}
\hline Reservoir & $\begin{array}{c}\text { Volume } \\
\left(\mathrm{m}^{3}\right)\end{array}$ & $\begin{array}{c}\text { Area } \\
\left(\mathrm{m}^{2}\right)\end{array}$ & $\begin{array}{c}\text { Drainage } \\
\text { area }\left(\mathrm{km}^{2}\right)\end{array}$ & $\begin{array}{c}\text { Dam heel } \\
(\mathrm{m} \text { a.s.l. })\end{array}$ & $\begin{array}{c}\text { Dam top } \\
(\mathrm{m} \text { a.s.l. })\end{array}$ & $\begin{array}{c}\text { Dam } \\
\text { length }(\mathrm{m})\end{array}$ \\
\hline P1 & 185,434 & 67,869 & 11.1 & 841 & 849 & 120 \\
P2 & 217,971 & 93,530 & 18.3 & 814 & 822 & 100 \\
P3 & 182,236 & 56,731 & 1.8 & 885 & 893 & 100 \\
P4 & 271,002 & 89,832 & 11.9 & 850 & 858 & 130 \\
\hline
\end{tabular}

Maidment et al. 2004). Advantages of the model are its freeware availability, user friendly arrangement and connection with GIS (Jeníček 2006).

The rainfall-runoff model HEC-HMS operates with a lumped and distributed modelling approach. To emphasize the heterogenity of the Rolava River basin it was required to divide the river basin to 29 sub-basins similar in area and in physical-geographical characteristics. Each component of rainfall-runoff process represented one sub-basin. Hence, each particular runoff parameter was individually expressed and did not describe the mean value of the whole basin.

The dry reservoir parameters, theoretically implemented in the basin model, were measured in the field (Table 1). All dry reservoirs were located in the upper flat part of the basin according to the DTM (Fig. 1). Two of the dry reservoirs were theoretically situated on the Rolava River (P1, P2), one dry reservoir on the Rolava's tributary the Jelení Brook (P3). The fourth dry reservoir was set on the Rolava's most important sinistral affluent the Slatinný Brook (P4). All dry reservoir shapes were measured by total geodetic station (TPS) in the field. Dry reservoirs capacities were calculated in ArcGIS from the DTM of each dry reservoir. The dry reservoir parameters were assigned in HEC-HMS to catch N100 rainfall on all dry reservoirs most significantly. Considering dry reservoirs, each dry reservoir was dimensioned using spillways, dam top and heel and different numbers of outlets. Dam was designed ideally as a concrete wall with outlets to retain river flow through the dam. Circle shaped outlets $(30 \mathrm{~cm}$ diameter) were assumed in four horizontal levels ( $1 \mathrm{~m}$ distance between two levels). Depending on the basin area drained, the number of outlets in levels differed per dry reservoir. To reach the most visible discharge drop in Stará Role, dry reservoir P1 had one outlet at the dam heel, two outlets in the second and third level and three outlets in the fourth level $(1,2,2,3)$. P2 dry reservoir had the same pattern, P3 and P4 dry reservoirs had 1,1,1,1 outlet pattern. The aim of this study was not to construct perfect technical structures but to compute theoretic dry reservoir impact on discharge drop in HEC-HMS environment and that is why the above used parameters were assumed. A different sub-basin size was drained by each dry reservoir. The consequence of that fact was that each dry reservoir had a different influence on the final runoff simulation.

\subsection{Methods}

The HEC-HMS uses a separate model to represent each component of the runoff process, including models for direct runoff, models that compute runoff volume, models for baseflow and models for channel flow (Feldman 2000). 
Clark's Unit Hydrograph (UH) method was chosen to account for the direct runoff as a part of the entire runoff. Clark's UH is one of the most used modelling methods in Czechia and abroad in similar kinds of papers (e.g. Kulasová, Šercl, Boháč 2004; Jeníček 2009). The UH is a commonly used empirical model of the relationship of direct runoff to excess precipitation. (Blažková 1993). The basin outflow resulting from one unit of direct runoff is generated uniformly over the drainage area at a uniform rainfall rate during a specified period of rainfall duration (Feldman 2000). Application of Clark's UH in HEC-HMS requires properties of the time-area function (time of concentration $T_{c}$ ) and the storage coefficient $R_{c}$ that is an index of the temporary storage of precipitation excess in the river basin as it drains to the outlet point (Feldman 2000).

The HEC-HMS computes runoff volume by taking into account the volume of water that is intercepted, infiltrated, stored, transpired or evaporated. Interception, infiltration, storage, evaporation and transpiration are collectively called losses in the program. The curve number $(\mathrm{CN})$ was used as a loss model resulting from SCS CN method (Soil Conservation Service Curve Numbers; Mishra, Singh 2003). The curve number represents the direct runoff rate of the runoff drained from the river basin (Mishra, Singh 2003). The HEC-HMS requires an estimated value of the initial abstraction $I_{a}$ that represent physical properties of the soils and land use and the antecedent conditions. If the river basin is in a saturated condition $I_{a}$ will be zero. If the river basin is dry $I_{a}$ will increase to represent the maximum precipitation depth that can fall on the river basin with no runoff (Feldman 2000). Determination of curve numbers suitably expressing Czech river basins was made with cooperation of the CHMI and the Research Institute for Soil and Water Conservation (Výzkumný ústav

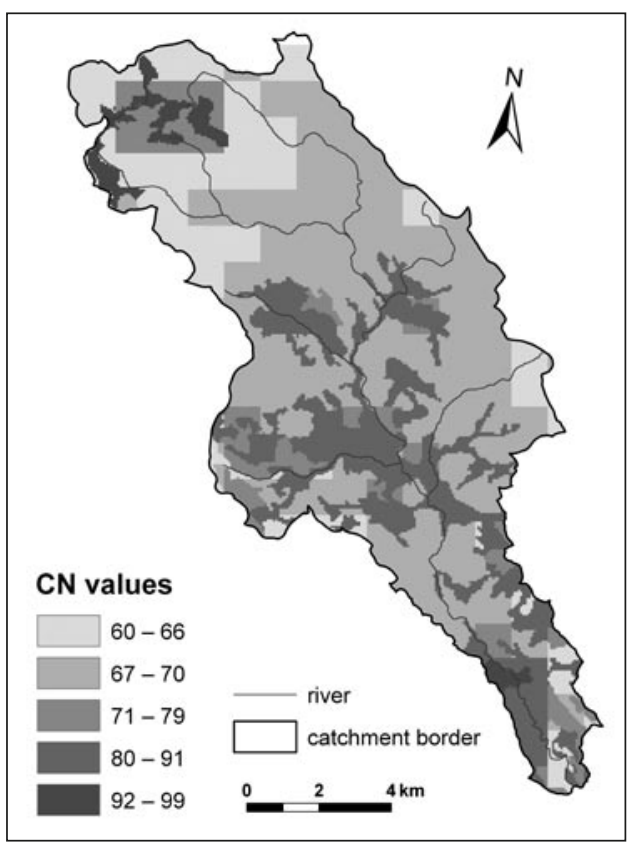

Fig. 2 - CN distribution (DIBAVOD, CHMI) meliorací a ochrany půd - VÚMOP; Šercl 2006). The determination method includes a grid estimation of soil infiltration capacity (spatial resolution $1 \mathrm{~km}^{2}$ ), storage capacity $\left(1 \mathrm{~km}^{2}\right)$ and slopes (DTM $\left.50 \mathrm{~m}\right)$. A combination of these parameters defines one of four categories of socalled hydrological soil groups. The hydrological soil group and land use category concludes the curve numbers. The final curve number distribution in the Rolava River basin is illustrated in Figure 2.

The HEC-HMS computes baseflow separately to direct runoff. An exponential Recession model is one of three alternative models of baseflow used in HEC-HMS. The recession model represents the drainage from natural storage in the river basin. It defines the relationship of baseflow at any time to an initial value. An exponential decay con- 
stant specifies flow rate. The baseflow displays mostly on the falling limb in comparison to direct runoff (Feldman 2000).

Modelling channel flows was carried out by the Muskingum-Cunge routing model. The Muskingum-Cunge model is based upon the solution of the continuity and diffusion wave form of the momentum equations. The HEC-HMS requires following parameters for reaches, which connect subbasins: the reach length and its slope gradient, the channel cross section configuration, the Manning's roughness coefficients of both river banks and the channel as well. An eight-point channel cross section configuration was measured by laser inclinometer and rangefinder.

\subsection{Time series processing}

Results coming from all the rainfall-runoff models are limited by the input data, their quality representation and up to date rate. The computation of rainfall runoff process in Rolava's river basin required spatially distributed rainfall data. The river basin mean areal precipitation depth was derived from the depths at rain-gauge stations using the Inverse Distance Weighted (IDW) method. The weights were computed and assigned to the gauging stations in inverse proportion to the square of the distance from the node to the gauging station. That meant nearer stations had a higher influence on the spatial precipitation distribution. Hence the orography in river basin is more specified as a precipitation distribution influencing factor, especially in the Ore Mountains.

Two known rainfall events were used to compute runoff in this paper. The basin model of Rolava was calibrated using a known flood event from 24th September 2007, 7:00 to 1st October 2007, 7:00 (GMT+1). The verification of the basin model ran on another known flood event from 4th August 2006, 7:00 to 10th August 2006, 7:00 (GMT+1). Using the calibration event, both the observed and simulated hydrographs were compared and adjusted with each other to find as similar curve as possible. The verification event was used to validate the success of the calibration process. It also allowed evaluating the rate of similarity of observed and simulated hydrograph. The similarity evaluation tool is, for example, the value of efficiency criterion. Both events were consistent with the meteorological cause and flood duration as well.

Four designed scenarios of 1-day precipitation with the return period of 10 , 20, 50 and 100 years were taken to illustrate the impact of the dry reservoir system on the hydrological regime. The 1-day precipitation amount was divided into hourly theoretical hyetographs in accordance with the approach of the CHMI (Kulasová et al. 2004).

\section{Results}

\subsection{Calibration and verification}

Calibration uses hydrometeorological data in a systematic search for parameters that represent the best fit of the computed results to the observed 

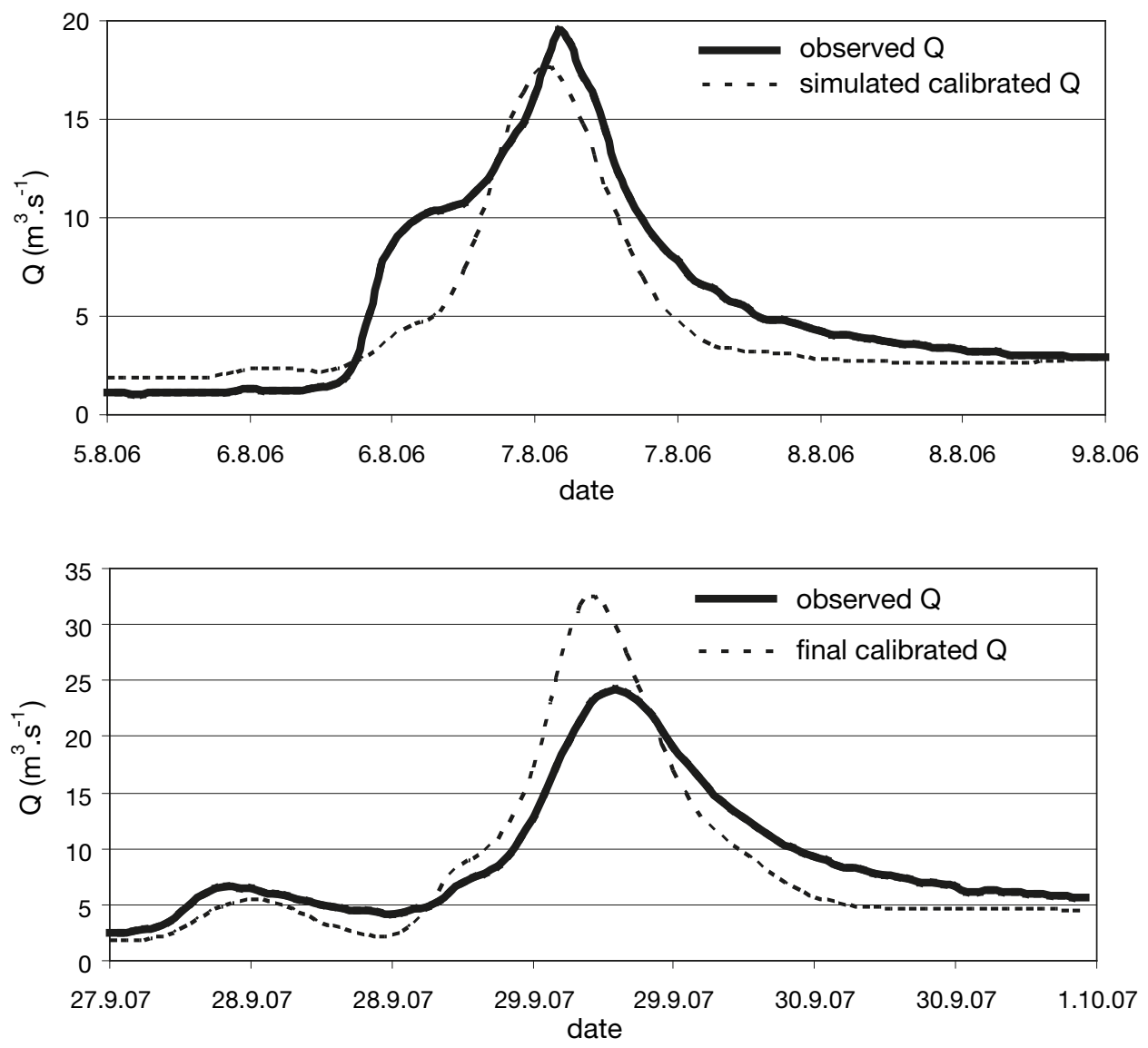

Fig. 3 - Hydrographs of September 2007 event (calibration) and of August 2006 event (verification)

runoff. Hydrological rainfall-runoff models offer manual and automatic calibration. Only some parameters can be calibrated in the HEC-HMS environment. The rate of similarity between observed and simulated hydrograph can be accounted, for example, by the Nash-Sutcliffe (N-S) value of the efficiency criterion. If the value is 1 , it means the absolute agreement of hydrographs (Nash, Sutcliffe 1970). Other options of similarity calculation are for instance the coefficient of determination or the index of agreement. The final $\mathrm{N}-\mathrm{S}$ value for the calibration event was 0.86 which means successful agreement. Both of the curves were similar but the difference between observed peak discharge and calibrated one showed visible deviation. The calibrated peak discharge was $25 \%$ higher than the observed peak discharge (Fig. 3).

Verification (optimization) validates on a verification event whether the calibration process was optimally defined and the calibrated parameters really suit other simulations (Daňhelka et al. 2003). The optimization showed the $\mathrm{N}-\mathrm{S}$ value of the efficiency criterion even higher than for the calibration, 0.89 . In reference to Abulohom, Shah, Ghumman (2001) the results of calibration 
and verification were classified as successful with high rate of the of $\mathrm{N}-\mathrm{S}$ agreement. The verified peak discharge was $9 \%$ higher than the observed one.

Initial abstraction, curve numbers, time of concentration, exponential decay constant and threshold rate in baseflow model were calibrated only. Curve numbers, initial abstraction and time of concentration were calibrated manually at first and afterwards automatically. The curve numbers were reduced during calibration process by up to $80 \%$ of original numbers. The time of concentration results demonstrated up to 1.5-6.5 times higher values when compared to the initially calculated values. Other calibrated values did not differ from the originals. The final hydrographs after calibration processes and verification are illustrated in Figure 3.

\subsection{Simulation with dry reservoir impacts}

By theoretically implementing four dry reservoirs to the headwater part of the Rolava River basin during two known rainfall events in August 2006 and September 2007 the discharge in the outlet Stará Role was reduced. The drop of in peak discharge was $4.8 \%$ for the September event case (from $31 \mathrm{~m}^{3} \cdot \mathrm{s}^{-1}$ to $29.5 \mathrm{~m}^{3} \cdot \mathrm{s}^{-1}$ ) and in August it was $7.4 \%$ (from $17.6 \mathrm{~m}^{3} \cdot \mathrm{s}^{-1}$ to $16.3 \mathrm{~m}^{3} \cdot \mathrm{s}^{-1}$ ).

Table 2 and Figure 4 illustrate the possible influence of the dry reservoir system on the maximum discharge decrease during the designed daily rainfall scenarios with the return period of 10, 20, 50 and 100 years (N10, N20, N50, N100). Figure 4 shows a short time frame to stress deviation in culmination with and without dry reservoir impact. In fact the volume difference between both curves correspods to the sum of the dry reservoir volumes. The simulations ran from the beginning of rainfall (time zero). The system of dry reservoirs proved its positive impact on the discharge drop during the extreme daily rainfall events. The positive impact means a peak discharge reduction and flood wave flattening. A part of the flood water was diverted to dry reservoirs and hence the peak discharges were decreased in the outlet Stará Role. Increasing the extremity of designed daily precipitation, the positive impact of dry reservoirs rose and caused a peak discharge $\left(Q_{k}\right)$ drop in the outlet. In the case of scenario N100 the peak discharge drop was by $19.1 \%$ and in the case of daily rainfall event N10 the peak discharge decreased by $12.9 \%$. The impact of the system of four dry reservoirs on the peak discharge reduction is expected to get more negative in dependence on the increasing extremity of the daily rainfall event. More of the extreme daily rainfall episodes with the return period of $\mathrm{N}>100$ years would probably cause overspill of the modelled dry reservoirs. The best option to decrease the discharge would occur during the

Table 2 - Simulation results

\begin{tabular}{|llllll|}
\hline Dry reservoir & Indicator & $\mathrm{N} 10$ & $\mathrm{~N} 20$ & $\mathrm{~N} 50$ & $\mathrm{~N} 100$ \\
\hline Without reservoirs & $\mathrm{Q}_{\mathrm{k}}\left(\mathrm{m}^{3} \cdot \mathrm{s}^{-1}\right)$ & 22.4 & 29.7 & 45.1 & 62.8 \\
With reservoirs & $\mathrm{Q}_{\mathrm{k}}\left(\mathrm{m}^{3} \cdot \mathrm{s}^{-1}\right)$ & 19.5 & 24.9 & 37.1 & 50.8 \\
$\begin{array}{l}\text { Change between with } \\
\text { and without reservoirs }\end{array}$ & $\mathrm{Q}_{\mathrm{k}}$ drop (\%) & 12.9 & 16.2 & 17.7 & 19.1 \\
\hline
\end{tabular}


N10

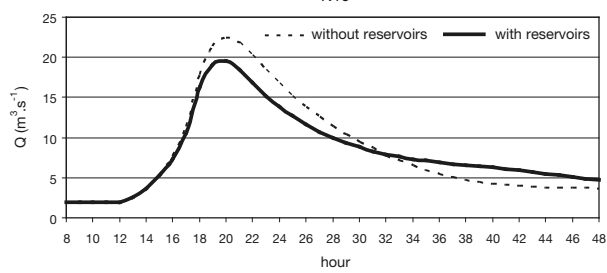

N20

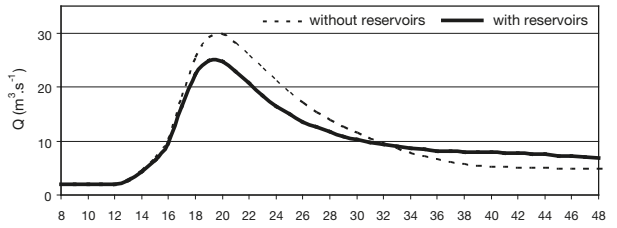

hou
N50

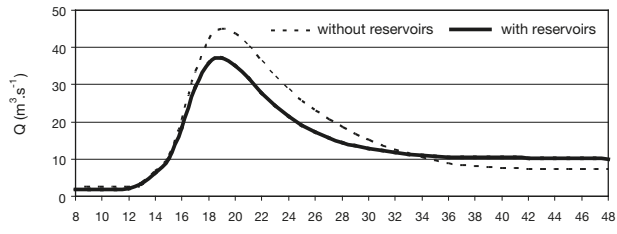

hour

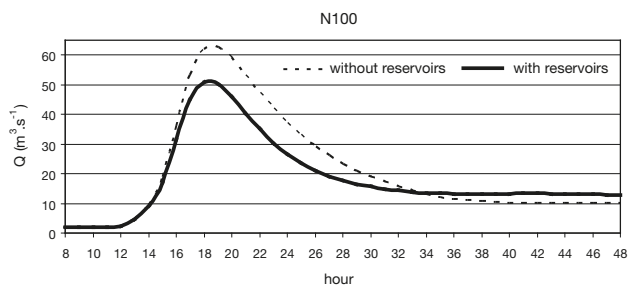

Fig. 4 - Hydrographs during the designed scenarios

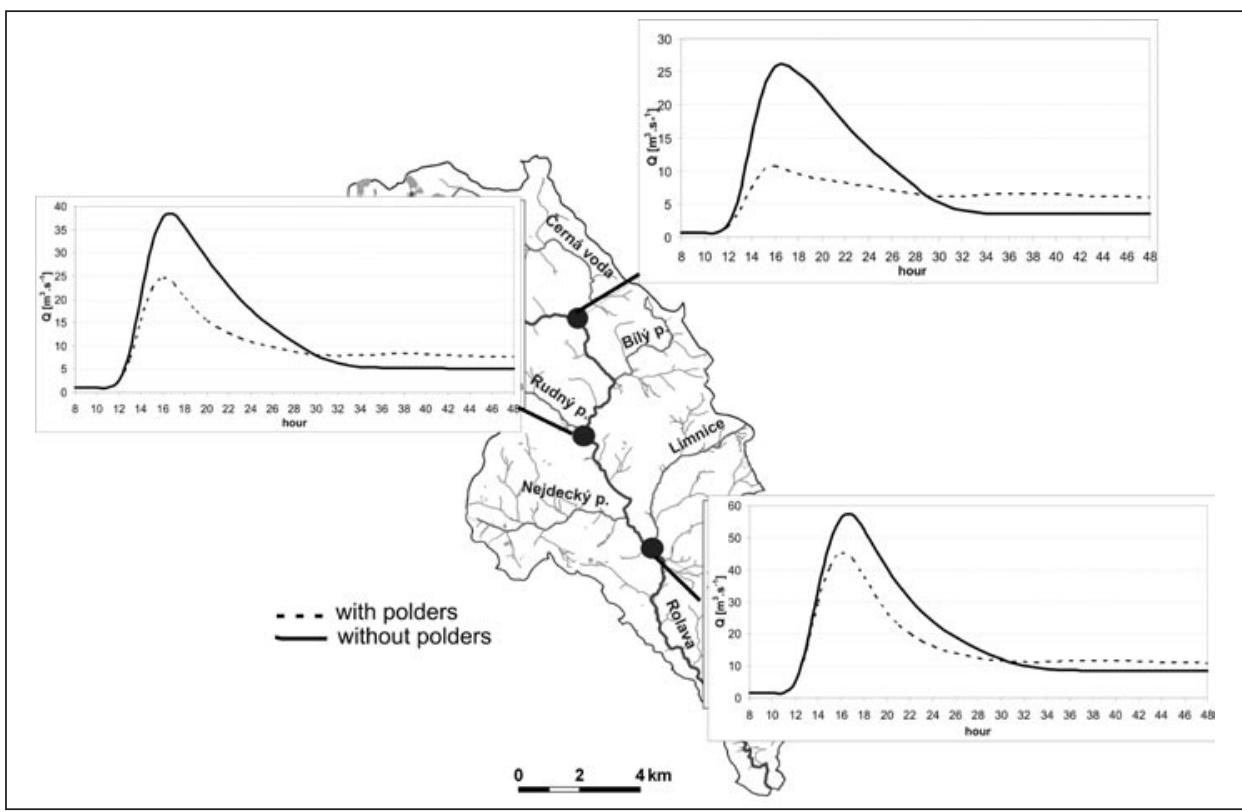

Fig. 5 - Variation of peak discharges in different parts of the basin with and without dry reservoir impacts

N100 event. More extreme rainfall events would influence the peak discharge in the outlet Stará Role in negative ways. The peak discharge would probably not be reduced much and in the most extreme cases it would be noticed that the maximum discharge is even higher than the maximum discharge without the impact of dry reservoirs.

The impact of dry reservoirs on the peak discharge drop is demonstrated with various intensity in the different parts of the Rolava River basin (Fig. 5). 
Table 3 - Dry reservoir impact in different parts of basin

\begin{tabular}{|c|c|c|c|c|c|c|}
\hline \multicolumn{7}{|c|}{ N100 } \\
\hline \multirow{2}{*}{$\begin{array}{l}\text { Peak discharge } \\
\left(\mathrm{m}^{3} \cdot \mathrm{s}^{-1}\right)\end{array}$} & \multicolumn{5}{|c|}{ Junction of the Rolava and brooks } & \multirow{2}{*}{$\begin{array}{c}\text { Outlet } \\
\text { Stará Role }\end{array}$} \\
\hline & Slatinný & Bílý & Rudný & Nejdecký & Limnice & \\
\hline without reservoirs & 25.9 & 30.4 & 38.2 & 51.5 & 57.0 & 62.8 \\
\hline with reservoirs & 10.7 & 16.3 & 24.6 & 39.7 & 45.1 & 50.8 \\
\hline$\%$ change & 58.7 & 46.4 & 35.6 & 22.9 & 20.9 & 19.1 \\
\hline
\end{tabular}

The most effective impact of the dry reservoirs was observed on the junction of Rolava and Slatinný Brook. The impact of four dry reservoirs became lower down the stream at the most important river junctions. The maximum discharge on the Rolava River and Slatinný Brook junction decreased by $58.7 \%$ during the N100 event when four dry reservoirs in the river basin were considered. This fact is predictable due to dry reservoir placement in the upper part of the river basin regrading any influence of other affluent rivers. The sinking impact of dry reservoirs on the peak discharge drop, is observed down the stream, was caused by many water bodies flowing to the main river (Table 3). Four dry reservoirs were supposed to keep the intensive precipitation totals in the upper part of the river basin.

\section{Discussion}

The use of hydrological models for rainfall-runoff modelling raises many uncertainties, issues and doubts. Generally the problems and uncertainties are divided into several categories being related to particular stages of model building. Selection of a suitable rainfall-runoff model, quality of input data, choice of spatial and time scale resolution, selection of accurate approaches for estimation of initial conditions of rainfall-runoff process and model calibration are considered to be the most complicated.

The rainfall-runoff simulations were carried out in the HEC-HMS that has been used for many hydrological analyses and projects in Czechia mentioned by Daňhelka et al. (2003); Kulasová, Šercl, Boháč (2004) or Roub and Pavlásek (2004). HEC-HMS has also already proved its applicability in Czech river basin environments. The quality of model input data could be burdened by mistakes mostly in the case of the curve numbers. Our curve numbers were calculated following the CHMI and VÚMOP method. The calculated values were overestimated as the calibration process showed. The overestimation could have been caused by the wide spatial resolution of grids $\left(1 \mathrm{~km}^{2}\right)$ that might not represent exactly the river basin area's heterogeneity.

The selection method for each component of the hydrological cycle was related to experience from previous model application and to the input data requests. Thereafter, the combination of the chosen methods influenced result simulations and that is why the results could be degraded by using a non-optimal combination of methods. The selection of methods was chosen according to several similar hydrological papers, for example, Daňhelka et al. (2003), Kulasová, Šercl, Boháč (2004), Śercl (2005), Jeníček (2009) etc. HEC-HMS 
offers the widest options for loss calculation. The SCS CN method is generally available and relatively simple. No representing of rainfall intensity and the problem of rainfall breaks belong to the disadvantages of this approach. If the maximum retention is exceeded, the infiltration value is zero instead of a constant nonzero value. The curve numbers have still the same values during the simulation process even though the soil saturation rises (Mishra, Singh 2003). SCS CN method is often criticized for its trivial physical background. However, it is regarded as one of the most widely used methods of loss estimation for Czech river basins. The plausibility of the curve number derivation directly affects the value of the potential area retention and thereby the direct runoff quantity as well. A lot of scientists prefer the physically more accurate Green and Ampt method of loss estimation. However, according to Kulasová, Šercel, Boháč (2004), this method is not suitable for steep forested soils in the mountain areas, which is the case of the Rolava River basin.

The model calibration was declared to be satisfactory as the $\mathrm{N}-\mathrm{S}$ value of the efficiency criterion was 0.86 . However, what must be considered are the differences between the calibrated and observed peak discharge values. That fact affects the final analyses description while the simulated results fluctuate within the fault interval from $10 \%$ to $20 \%$. The curve numbers were the most optimized during the calibration process. The curve numbers calculated according to Šercl (2005) represented mean values. However the simulation results could be influenced by initial soil saturation. If there was no soil saturation before rainfall, the curve numbers would be lower. Šercl (2005) also describes the SCS CN calculation method for the dry period and the saturated soil before rainfall. Our calibrated curve numbers were $80 \%$ of initially estimated values. The calibrated values corresponded to curve numbers for a dry period before rainfall based on Šercl's estimation formula for dry periods. The result of calibration indicated that there had been no other precipitation immediately before the rainfall event started.

Dry reservoir parameters were assumed as for rainfall event N100. Technical accuracy of their construction was not considered as the main aim of the paper. Instead the parameters used, corresponded to the model's potentials. The paper represents a theoretic case study in a particular HEC-HMS environment involving the best approaches of the software.

\section{Conclusion}

The simulation of rainfall-runoff processes during known and designed rainfall events were carried out in HEC-HMS. The model HEC-HMS showed its applicability for the hydrological analyses in the Rolava River basin in terms of model's potentials. HEC-HMS lacks the capability to hydraullic modelling of flood wave transformation within a dry reservoir. HEC-HMS provides information about dry reservoir impact on discharge drop in the outlet taking into account a dry reservoir as an uncontrolled reservoir that rivers flow through.

Calibration and verification were necessary steps before simulation runs. The main aim of the calibration was to depict the real character of the Rolava's river basin area as well as possible. The result of manual and automatic cali- 
bration was the value of the similarity assessed by the Nash-Sutcliffe value of the efficiency criterion, 0.86 . Verification was even more successful, 0.89 .

The system of four theoretically implemented dry reservoirs showed its impact on the peak discharge decrease during the designed daily scenarios with the return period of 10, 20, 50 and 100 years. The positive impact of four dry reservoirs increased with the rainfall extremity up to $\mathrm{N}=100$ years. Higher rainfall extremities would probably cause dam overspill on all dry reservoirs. The dry reservoirs proved to be most efficient in the upper part of the river basin on the junction of the Rolava River and Slatinný Brook. The purpose of the system of four dry reservoirs as flood arrangements was confirmed in the study area.

Due to the combination of proper rainfall-runoff modelling methods the basin model of the Rolava River was calibrated and it is ready for other hydrological analyses in that river basin area. However, it is necessary to take into account calibration faults and uncertainties and simplification of dry reservoir parameters.

\section{References:}

ABULOHOM, M.S., SHAH, S.M.S., GHUMMAN, A.R. (2001): Development of RainfallRunoff model, its Calibration and Validation. Water Resources Management, 15, No. 3, pp. 149-163.

BLAŽKOVÁ, Š. (1993): Srážko-odtokové modelování založené na principu jednotkového hydrogramu. Výzkumný ústav vodohospodářský T. G. Masaryka. Praha, 114 pp.

BRATH, A., MONTANARI, A., MORETTI, G. (2005): Assessing the effect on flood frequency of land use change via hydrological simulation (with uncertainty). Journal of Hydrology, 324 , No 1-4, pp. 141-153.

DAŇHELKA, J., KREJČÍ, J., ŠÁLEK, M., ŠERCL, P., ZEZULÁK, J. (2003): Posouzení vhodnosti aplikace srážko-odtokových modelů s ohledem na simulaci povodňových stavů pro lokality na území ČR. Český hydrometeorologický ústav. Praha, 196 pp.

FELDMAN, A.D. (2000): Hydrologic Modeling System HEC-HMS. Technical Reference Manual. USACE, Davis, $155 \mathrm{pp}$.

HERYNEK, J., TLAPÁK, V. (2002): Malé vodní nádrže. Mendelova zemědělská a lesnická univerzita v Brně. Brno, 200 pp.

JANSKÝ, B., KOCUM, J. (2008): Peat bogs influence on runoff process: case study of the Vydra and Křemelná River basins in the Šumava Mountains, southwestern Czechia. Geografie, 113, No. 4, pp. 383-399.

JENÍČEK, M. (2009): Runoff changes in areas differing in land-use in the Blanice River basin - application of the deterministic model. Journal of Hydrology and Hydromechanics, 57, No. 3, pp. 154-161.

JENÍČEK, M. (2008): Modelling the effect of small reservoirs on flood regime in the Chomutovka river basin. In Brilly, M., Šraj, M. (eds.): XXIVth Conference of the Danubian Countries on the Hydrological Forecasting and Hydrological Bases of Water Management. Slovenian National Committee for the IHP UNESCO, Ljubljana, pp. 1-7.

JENÍČEK, M. (2006): Rainfall-runoff modelling in small and middle-large catchments - an overview. Geografie, 111, No. 3, pp. 305-313.

JUST, T. et al. (2005): Vodohospodářské revitalizace a jejich uplatnění v ochraně před povodněmi. Český svaz ochránců přírody, Agentura ochrany přírody a krajiny ČR, MŽP, Praha, 359 pp.

KLIMENT, Z., MATOUŠKOVÁ, M. (2009): Runoff changes in the Šumava Mountains (Black Forest) and foothill regions: Extent of influence by Human Impact and Climate Changes. Water Resources Management, 23, No. 1-4, pp. 1813-1834.

KULASOVÁ, B., ŠERCL, P., BOHÁČ, M. (2004): Projekt QD1368 „Verifikace metod odvození hydrologických podkladů pro posuzování bezpečnosti vodních děl za povodní“. Závěrečná zpráva. CHMÚ, Praha, 127 pp. 
LANGHAMMER, J. (2008): Applicability of hydromorphological monitoring data to locate flood risk reduction measures: Blanice river basin, Czech Republic. Environmental Monitoring and Assessment, 152, No. 1-4, pp. 379-392.

LANGHAMMER, J., ŠOBR, M., VANĚK, T. (2008): Současné přístupy k řešení protipovodňové ochrany na příkladu povodí horní Opavy. In: Langhammer, J. (2008): Údolní niva jako prostor ovlivňující průběh a následky povodní. PřF UK, Praha, pp. 52-70.

LANGHAMMER, J., VILÍMEK, V., KŘIŽEK, M. (2003). Posouzení efektivnosti změn ve využívání krajiny pro retenci a retardaci vody jako preventivní opatření před povodněmi. Závěrečná zpráva projektu „Vyhodnocení katastrofální povodně v srpnu 2002“ vlády ČR. PřF UK, Praha. 74 pp.

MAIDMENT, D.R., KNEBL, M.R., YANG, Z.L., HUTSCHISON, K. (2004): Regional scale flood modeling using NEXRAD rainfall, GIS, and HEC-HMS/RAS: a case study for the San Antonio River Basin Summer 2002 storm event. Journal of Environmental Management, 75 , No. 4, pp. 325-336.

MAIDMENT, D.R. (1993): Handbook of hydrology. McGraw-Hill, New York, 1424 pp.

MISHRA, S.K., SINGH, V.P. (2003): Soil Conservation Service curve number (SCS-CN) methodology. Kluwer, Drdecht, 513 pp.

NASH, J. E., SUTCLIFFE, J. V. (1970): River flow forecasting through conceptual models part I - a Discussion of principles. Journal of Hydrology, 10, No. 3, pp. 282-290.

ROUB, R., PAVLÁSEK, J. (2004): Comparison of models DesQ-MAX Q and HEC-HMS. Sustain Life Secure Surfoval II, Social and Environmentally Responsible Agribusiness, 22-25 September; CD-ROM, Praha.

ŠERCL, P. (2005): Metodický postup ČHMÚ pro odvození teoretických povodňových vln deterministickými přístupy. In: Návrhové průtoky a objemy povodňových vln na velmi malých povodích. ČZU, Praha, pp. 11-12.

ŠERCL, P. (2006): Rozvoj a testování modelovacího systému pro predikci povodňových odtoků v malých povodích, DÚ $3 \mathrm{VaV} 1 \mathrm{D} / 1 / 5 / 05$.

VILÍMEK, V., SPILKOVÁ. J. (2009): Natural hazards and risks: the view from the junction of natural and social sciences. Geografie, 114, No. 4, pp. 332-349.

\section{Shrnutí}

\section{VLIV SYSTÉMU POLDRŮ NA PRŮBĚH POVODNÍ V POVODÍ ROLAVY}

Účinná koncepce protipovodňové ochrany patří k aktuálním tématům výzkumu v oblasti hydrologie. V současné době existuje mnoho systémů protipovodňové ochrany, které se prokázaly za povodňových situací jako úspěšné. Úspěšnost takových návrhů je relevantní, dojde-li ke snížení kulminačních průtoků a celkovému zmenšení ničivého účinku vody na sídla a lidskou společnost. Vedle technických protipovodňových opatření hrají významnou roli v přírodně zachovalých lokalitách opatření prrírodě blízká, která nevyžadují drastický zásah do krajiny, a přesto dokáží velikost povodně transformovat. Příkladem jsou stále častěji využívané malé vodní nádrže podle definice ČSN 75 2410, tedy nádrže s objemem menším než 2 mil. $\mathrm{m}^{3}$ a hloubkou maximálně $9 \mathrm{~m}$. Konkrétním př́kladem použitým v tomto článku je typ malé vodní nádrže průtočný poldr. Průtočné poldry částečně akumulují vodu při zvýšených odtocích, zmenšují maximální průtoky a zpomalují průchod povodňových vln. Budování poldrů je žádoucí na povodněmi ohrožených místech, kde je nemožná aplikace technických opatření. V horních partiích horských povodí systém poldrů může efektivně transformovat vodu z intenzivních deštů. Předkládaná studie se zabývá hodnocením vlivu teoreticky implementovaného systému čtyř průtočných poldrů do horní části povodí Rolavy v Krušných horách na povodňové události.

Hlavní cíle se dotýkaly správné analýzy chování povodí Rolavy během zvolených srážkových epizod pomocí software HEC-HMS. Zhodnocení vlivu čtyř průtočných poldrů na snížení kulminace v závěrovém profilu během dvou známých událostí a čtyř denních srážkových scénářủ s dobou opakování 10, 20,50 a 100 let patřilo ke hlavním cílům práce. V prostředí HEC-HMS byl sestaven model povodí, který co nejpřesněji odpovídal charakteru studovaného území. Ačkoliv modelování ukázalo na řadu nejistot, prokázala úspěšná kalibrace a verifikace modelu jeho použitelnost pro modelování teoretických událostí. 
Modelování odtoku probíhalo ve srážko-odtokovém modelu HEC-HMS, který se osvědčil v mnoha podobných studiích v Česku i v zahraničí. Přednostmi modelu jsou jeho volná dostupnost, přehlednost, uživatelská jednoduchost a aplikovatelnost na česká povodí. Samotnému modelování předcházely analýzy digitálního modelu terénu a zpracování známých dat o srážkových úhrnech a průtocích. Poldry byly vyměřeny v terénu totální geodetickou stanicí. Model povodí je v HEC-HMS popsán čtyřmi základními komponentami, jejichž vyjádření podléhá výběru vhodné metody.

Komponenta přímého odtoku byla řešena metodou Clarkova jednotkového hydrogramu. Výpočet objemu odtoku byl vyčíslen metodou SCS CN (Soil Conservation Service Curve Numbers), která pro území o gridu $1 \times 1 \mathrm{~km}$ uvažuje infiltrační schopnost půd, retenční vodní kapacitu a sklonitost terénu. Komponenta podzemního odtoku byla zjištěna metodou exponenciálního poklesu. Metoda Muskingum-Cunge sloužila k odhadům parametrů komponenty korytového modelu s vyjádřením drsnostních koeficientů podle Manninga.

Model povodí byl kalibrován na srážkové události 24.9.-1.10.2007 a ověřen na události 4. 8. - 10. 8.2006. Pro obě události byl simulován průtok v závěrovém profilu s vlivem poldrů a porovnán se skutečnými hodnotami průtoků dodanými Českým hydrometeorologickým ústavem. Klíčové pro studii bylo sledování vlivu systému poldrů při variantních srážkových scénářích s dobou opakování 10, 20, 50 a 100 let. Denní scénáře srážkových úhrnů byly rozloženy do 24hodinového návrhového hyetogramu dle metodiky Kulasová, Šercl, Boháč (2004).

Simulované hydrogramy měly velkou vypovídací hodnotu, nebot' kalibrační i verifikační proces prokázal podobnost pozorovaných a simulovaných křivek na uspokojivé úrovni se shodou Nash-Sutcliffe 0,86 a 0,89 . Vliv poldrů na zmenšení kulminačních prütoků v závěrovém profilu Stará Role byl jasně prokázán na známých událostech i na variantních scénářích. S rostoucí extremitou srážkového úhrnu roste i pozitivní vliv poldrů, které účinně transformují část povodně v horní části povodí Rolavy. Je však pravděpodobné, že vliv podlrů při událostech extrémnějších než $\mathrm{N}=100$ bude klesat. Nejprokazatelnější vliv je pod nádržemi. Směrem po toku klesá pozitivní vliv poldrů vlivem větších přítoků níže na toku.

Role protipovodňové ochrany na příkladu poldrů se na zvoleném území jeví jako smysluplná. Jedná se však o teoretickou studii, která aplikuje konkrétní software a která by v případě realizace potřebovala množství dalších výpočtů včetně technického zabezpečení hrází a podrobného hydraulického modelování, což zvolený software HEC-HMS neumožňuje. Software neumožňuje manipulaci na poldrech a popisuje poldr jako neřízenou nádrž, která vodu nesaturuje. Parametry poldrů byly v modelu dimenzovány na srážky N100. V případě vyšších srážek než N100 by vliv poldrů byl pravděpodobně negativní a očekával by se neřízený přeliv vody přes hráz. Zvolená kombinace metod v HEC-HMS se v české hydrologické praxi objevuje často, přesto je nutné počítat $\mathrm{s}$ možnými nepřesnostmi a chybami. Možné nedostatky simulací je potřeba eliminovat co nejpřesnějším vyjádřením modelu povodí tak, aby se co nejvíce přiblížil skutečnosti. Každé povodí je však velmi heterogenní a jeho dílčí fyzickogeograficky rozmanitá subpovodí není v lidských silách přesně postihnout.

Obr. 1 - Výškové poměry a hydrografie povodí Rolavy (DIBAVOD, ZABAGED)

Obr. 2 - Výsledné hodnoty CN pro povodí Rolavy (DIBAVOD, ČHMÚ)

Obr. 3 - Hydrogramy pro epizodu září 2007 (kalibrace) a srpen 2006 (verifikace)

Obr. 4 - Hydrogramy průtoků během denních srážkových úhrnů s dobou opakování $\mathrm{N}$

Obr. 5 - Odlišný vliv nádrží na zmenšení kulminačních průtoků na různých soutocích

Authors'affiliations: Charles University in Prague, Faculty of Science, Department of Physical Geography and Geoecology, Albertov 6, 12843 Praha 2, Czechia; e-mail: alice.taufmann@centrum.cz, jenicek@natur.cuni.cz.

Initial submission, 21 April 2010; final acceptance, 15 March 2011.

\section{Please cite this article as:}

TAUFMANNOVÁ, A., JENÍČ́EK, M. (2011): Impact of polder system on flooding in the Rolava River basin. Geografie, 116, No. 2, pp. 130-143. 